Diabetologia 8, 206-210 (1972)

(C) by Springer-Verlag 1972

\title{
Partial Pancreatectomy and the Role of Insulin in Carbohydrate Metabolism in Gallus Domesticus
}

\author{
D.R. LangsLow and B.M. Freeman \\ Houghton Poultry Research Station, Houghton, Huntingdon PE 17 2DA, England
}

Received: January 3, 1972, accepted: March 8, 1972

\begin{abstract}
Summary. A technique for the partial pancreatectomy of the chicken is described. Following surgery the plasma insulin concentration falls from $78 \mu \mathrm{U} / \mathrm{ml}$ to $17.5 \mu \mathrm{U} / \mathrm{ml}$ and remains at that level for the subsequent 2 days of observations. No persistent hyperglycaemia was noted and the birds became hypoglycaemic after 2 days. Plasma FFA concentration was significantly reduced throughout. The partially pancreatectomized chicken was found to have a severely impaired glucose tolerance and there was only a slight, non-significant increase in plasma insulin after glucose loading. Its response to glucagon was little changed. It is concluded that insulin plays an essential role in the utilization of glucose but the site of its action remains to be identified.
\end{abstract}

Ablation partielle du paneréas et rôle de l'insuline dans le métabolisme des hydrates de carbone chez le Gallus domesticus

Résumé. On décrit une technique pour l'ablation partielle du pancréas du poulet. Après l'opération chirurgicale, la teneur plasmatique en insuline tombe de $78 \mu \mathrm{U} /$ $\mathrm{ml}$ à $17.5 \mu \mathrm{U} / \mathrm{ml}$ et demeure à ce niveau pendant les deux jours suivants. Aucune trace d'hyperglycémie persistante n'est observée, et les oiseaux deviennent hypoglycémiques au bout de deux jours. La teneur en acides gras libres du plasma est considérablement réduite pendant toute la durée de l'expérience. L'ablation partielle du pancréas provoque chez le poulet un affaiblissement très marqué de la tolérance au glucose, et on observe seulement une légère augmentation d'insuline plasmatique, d'importance insignifiante, après charge de glucose. La réponse au glucagon ne change guère. On en conclut que l'insuline joue un rôle essentiel dans l'utilisation du glucose, mais le site même de cette réaction n'a pas encore été localisé.

Partielle Pankreatektomie und die Bedeutung des Insulins im Stoffwechsel der Kohlenhydrate des Haushuhns (Gallus domesticus)

Zusammenfassung. Eine Technil zur partiellen Entfernung der Bauchspeicheldruise des Huhns wird beschrieben. Nach der Operation fällt die Plasmainsulinkonzentration von $78 \mu \mathrm{U} / \mathrm{ml}$ auf $17.5 \mu \mathrm{U} / \mathrm{ml}$ und bleibt während der nächsten 2 Beobachtungstage in dieser Höhe. Eine anhaltende Hyperglykämie ließ sich nicht feststellen; die Tiere wurden nach 2 Tagen hypoglykämisch. Die Konzentration der freien Fettsäuren verringerte sich signifikant während der ganzen Zeit. Das partiell pankreatektomierte Huhn weist eine stark beeinträchtigte Glucosetoleranz auf. Es ließ sich nur eine leichte, nicht signifikante $\mathrm{Zu}$ nahme des Plasmainsulins nach Glucosegabe feststellen. Seine Reaktion auf Glucagon änderte sich wenig. Man kann daraus schließen, daß Insulin eine wichtige Rolle bei der Utilisation der Glucose spielt. Der Wirkungsort muß noch identifiziert werden.

Key words: Pancreatectomy, glucagon, glucose tolerance, plasma glucose, plasma FFA, plasma insulin, chicken.

\section{Introduction}

The role of insulin in the regulation of carbohydrate and lipid metabolism in birds is uncertain. The differences between bird and mammal were highlighted by Minkowski's (1893) observation that pancreatectomized ducks and geese did not develop diabetes mellitus. Whilst there have been many conflicting reports published over the years (see a review by Langslow and Hales, 1971) this central observation has never seriously been challenged.

The chicken is extremely insensitive to injected insulin; doses as large as $50 \mathrm{i} . \mathrm{u} . / \mathrm{kg}$ body weight producing nothing more than a mild hypoglycaemia and an increase in the concentration of plasma free fatty acids (FFA) (Heald et al., 1965; Lepkovsky et al., 1967; Langslow et al., 1970). This effect on FFA is the reverse of that seen in mammals.

Once differences in the primary structures of avian and mammalian insulins had been demonstrated (Smith, 1966) the question was asked whether the chicken's insensitivity to mammalian insulin was merely a reflection of those differences. However, it is now known that the two insulins have similar potencies in vitro (Goodridge, 1968b; Hazelwood et al., 1968; Langslow and Hales, 1969; Langslow, 1971) and similar half-lives in chicken plasma (Langslow and Kimmel, 1972).

In order to investigate further the role of insulin in chickens, an insulin-deficient bird is required. Unfortunately neither alloxan (Scott et al., 1945; Lukens, 1948; Mirsky and Gitelson, 1957; Langslow et al., 1970) nor streptozotocin (Langslow, 1970; Langslow et al., 1970) has any specific effect on the $\beta$-cells of the islets of Langerhans and the plasma glucose, FFA and insulin concentrations are unchanged even when the doses are well in excess of those affecting mammals. Thus surgical methods offer the only sure means of producing insulin-deficient chickens.

Since our immediate aim would be satisfied if we could reduce the level of circulating insulin, we decided to attempt no more than a partial pancreatectomy as 
total pancreatectomy is extremely difficult to achieve because of the anatomical relationships between the pancreas and gut. A technique was developed which allowed the removal of a large proportion of the pancreas in a relatively short time thereby achieving, it was hoped, the maximum effoct on plasma insulin levels with a minimum of surgical trauma. This report describes this technique and the effect that it produced on the plasma glucose, FFA, insulin and $\alpha$-amino nitrogen concentrations and on the response of the chicken to glucose and glucagon.

\section{Materials and Methods}

Surgical technique. All experiments were carried out on Rhode Island Red chickens aged between 3 and 4 weeks. Anaesthesia was induced by an intraperitoneal injection of tribromoethyl alcohol (Avertin, Bayer Products). To $25 \mathrm{ml}$ physiological saline were added $2 \mathrm{ml}$ ethanol and then $0.5 \mathrm{ml}(0.5 \mathrm{~g})$ Avertin, drop by drop with vigorous shaking. Deep anaesthesia was obtained within 20 to $25 \mathrm{~min}$ following the injection of this solution at a dose rate of approximately $8 \mathrm{ml} / \mathrm{kg}$ body weight (145 $\mathrm{mg}$ Avertin $/ \mathrm{kg}$ ).

The duodenal loop was quickly exposed through a $3 \mathrm{~cm}$ incision on the right side of the abdomen. It was flexed cranially to expose the vascular connections (branches of the gastroduodenal artery and vein) between the duodenum and pancreas and the caeca which were then ligatured and cut. Next a double ligature was applied to the main artery and vein at a more proximal point along the duodenal loop. Immediately these ligatures had been tied the distal pancreatic tissue was cut away leaving the duodenal loop intact but largely avascular. After replacing the exposed duodenum in the abdominal cavity, the musculature of the body wall and then the skin were sutured. The complete surgical procedure required about $20 \mathrm{~min}$.

Following surgery the birds were placed in an incubator. Consciousness returned usually within $6 \mathrm{~h}$. The birds showed no inclination to eat or drink after the operation. It is thought that the destruction of the vascular system of a major part of the duodenum may have been responsible. The subsequent fall in body weight resulted from this and was not a consequence of pancreatectomy per se since in both normal starved and partially pancreatectomized birds the reductions were similar: their mean respective weights were $201 \mathrm{~g}$ and $199 \mathrm{~g}$ on the day of surgery, $177 \mathrm{~g}$ and $175 \mathrm{~g} 1$ day later and $158 \mathrm{~g}$ and $157 \mathrm{~g}$ 2 days later.

The technique described above allowed the removal of about $80 \%$ of the pancreas: the mean weight of pancreatic tissue following surgery was $196 \mathrm{mg}$ while the whole pancreas weighed, on average, $1037 \mathrm{mg}$.

Collection of blood samples and injection of chickens. Both glucose $(0.5 \mathrm{~g} / \mathrm{bird})$ and glucagon $(10 \mu \mathrm{g} / \mathrm{kg}$ body weight) were given by intracardiac injection in sterile saline $(0.9 \%)$. Samples of blood $(1 \mathrm{ml})$ were withdrawn by frontal cardiac puncture without anaesthesia and rapidly transferred to tubes containing heparin. They were stored in an ice-bath before separation of the plasma by centrifugation. The plasma samples were stored at $-20^{\circ} \mathrm{C}$ until analyzed.

Analytical methods. Plasma insulin was measured by a modification of Hales and Randle's (1963) method $\mathrm{C}$ as described by Langslow et al. (1970) except that pure chicken insulin (kindly given by Professor J.R. Kimmel, Kansas University Medical Center, Kansas City, Kansas) was used as the insulin standard. Plasma glucose was measured by the glucose oxidase method of Huggett and Nixon (1957). The total plasma $\alpha$-amino nitrogen concen- tration was determined on an aliquot of a protein-free Folin and Wu filtrate by the colorimetric ninhydrin method of Moore and Stein (1954). Plasma FFA concentration was determined by the copper-triethylamine method of Laurell and Tibling (1967).

\section{Results}

The effects of pancreatectomy. The plasma glucose, FFA, insulin and $\alpha$-amino nitrogen concentrations were measured on each of the three days following surgery. There was a sharp (80\%) fall in the plasma insulin concentration after $24 \mathrm{~h}$ (Fig. 1) and it there-

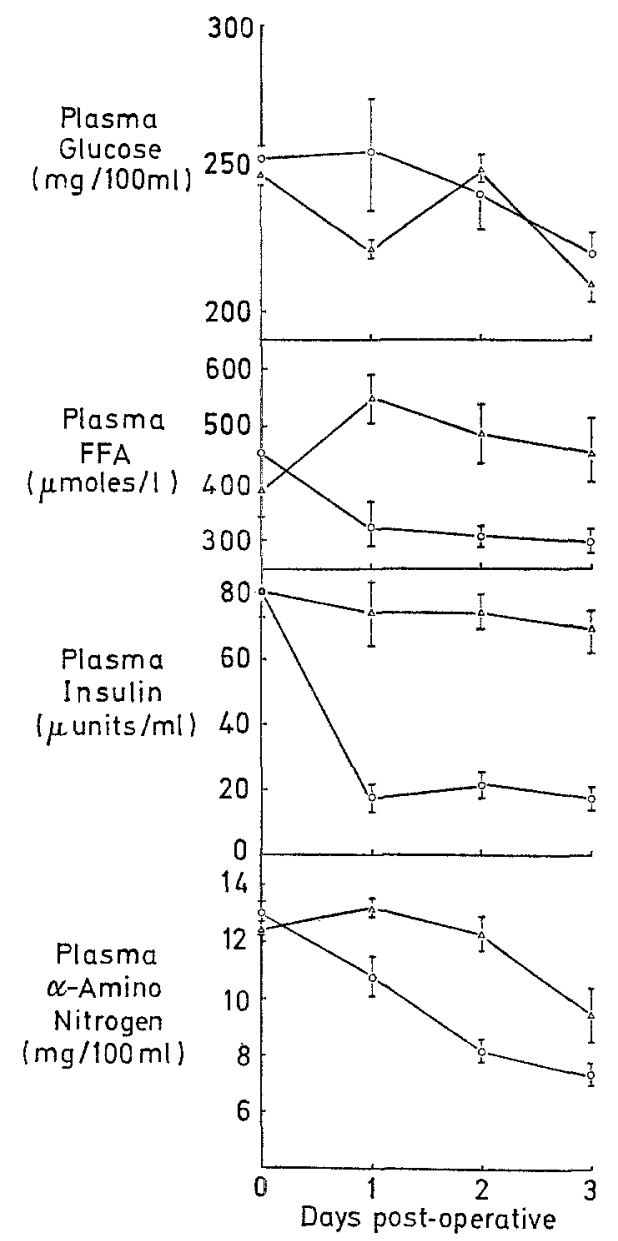

Fig. 1. The effect of partial pancreatectomy on plasma glucose, FFA, insulin and $\alpha$-amino nitrogen concentrations. Each point is the mean of at least seven observations; standard errors are indicated. $O=$ partially pancreatectomized; $\Delta=$ intact. (The two groups were of equivalent nutritional status)

after remained around $17.5 \mu \mathrm{U} / \mathrm{ml}$, up to $72 \mathrm{~h}$. The magnitude of this fall corresponds almost exactly with the amount of pancreas removed. Since the partially pancreatectomized birds did not feed, the control groups of birds in these experiments were always starved for an equal length of time. 
The plasma glucose concentration of the partially pancreatectomized chickens was maintained for $24 \mathrm{~h}$, but fell thereafter (Fig. 1). The intact chickens showed the normal response to starvation with a small fall in plasma glucose concentration after $24 \mathrm{~h}$, a rise at $48 \mathrm{~h}$ and then another fall. There was a compensatory increase in their plasma FFA concentration. In contrast, however, the partially pancreatectomized chickens showed a significant fall in plasma FFA concentration. Their plasma $\alpha$-amino nitrogen concentration also fell while that of the starved chickens increased for $24 \mathrm{~h}$ before falling (Fig. 1).

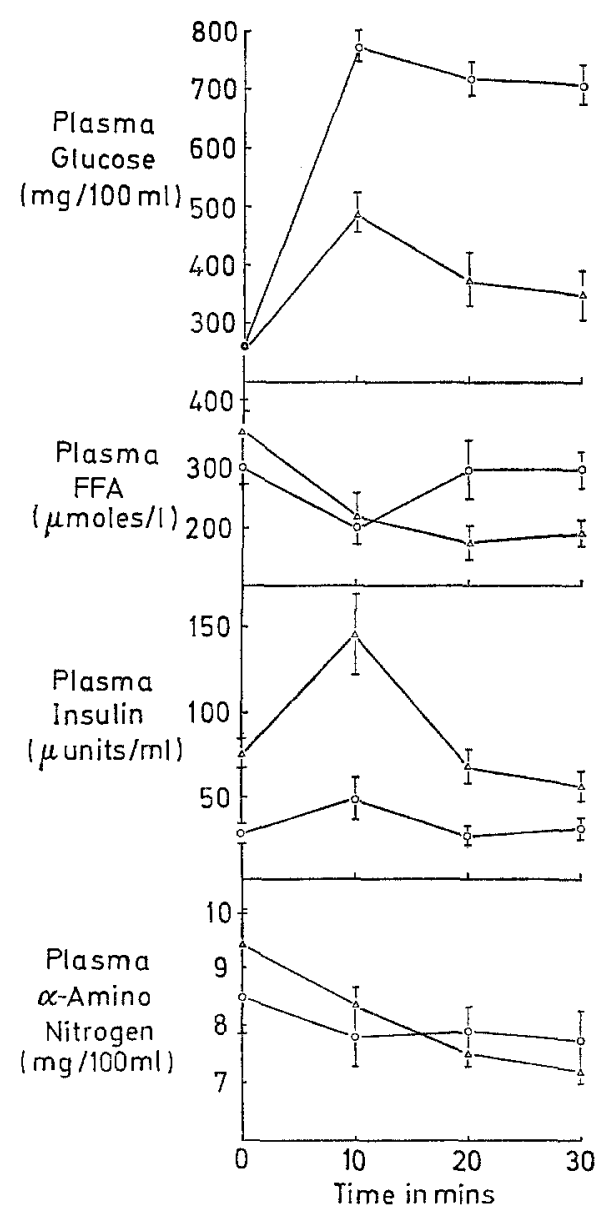

Fig. 2. Glucose tolerance tests on partially pancreatectomized $(0)$ and intact $(\Delta)$ chickens. Each chicken was given $0.5 \mathrm{~g}$ of glucose by intracardiac injection at time 0 . Each point is the mean of at least seven observations; standard errors are indicated

The chickens used for subsequent experimentation were taken two days after surgery. This was considered to be a reasonable time after the operation so that the chicken was in an altered metabolic state but over the immediate trauma of the surgery. No bird, whether pancreatectomized or intact, was subjected to more than one test.
Glucose tolerance tests. Each chicken was given $0.5 \mathrm{~g}$ glucose in $0.5 \mathrm{ml}$ physiological saline intracardially. The plasma glucose concentration of the partially pancreatectomized chickens rose to $778 \mathrm{mg} / 100 \mathrm{ml}$ $10 \mathrm{~min}$ after the injection and was still over $700 \mathrm{mg} /$ $100 \mathrm{ml}$ after $30 \mathrm{~min}$ (Fig. 2). The plasma glucose concentration of the intact chickens, in contrast, was $487 \mathrm{mg} / 100 \mathrm{ml}$ after $10 \mathrm{~min}$ and at $30 \mathrm{~min}$ had declined to $300 \mathrm{mg} / 100 \mathrm{ml}$.

There was also a striking difference in the response of the plasma insulin concentration. In the operated chickens, there was a small, but non-significant,

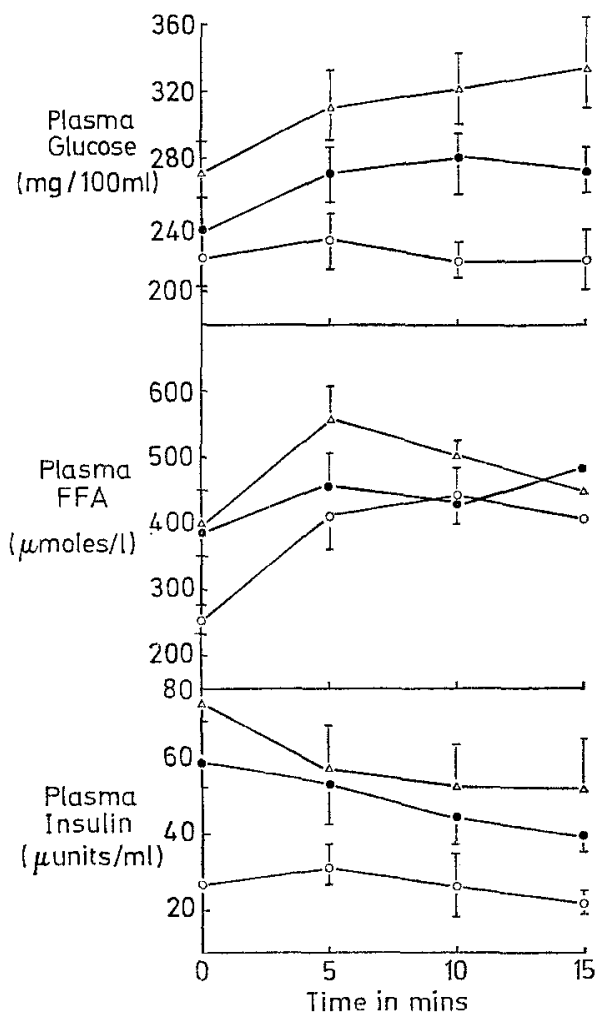

Fig. 3. The effect of glucagon $(10 \mu \mathrm{g} / \mathrm{kg}$ by intracardiac injection) on plasma glucose, FFA and insulin of partially pancreatectomized, starved (O), intact, starved (O) and intact, fed $(\triangle)$ chickens. The glucagon was given at time 0 . Each point is the mean of at least five observations; standard errors are indicated

increase in the plasma insulin concentration after $10 \mathrm{~min}$, but the increase in intact chickens was highly significant. The plasma FFA concentration of both groups of chickens fell significantly after $10 \mathrm{~min}$. While the plasma FFA of the intact chickens remained depressed, that of the partially pancreatectomized chickens returned to the initial concentration after $20 \mathrm{~min}$. The plasma $\alpha$-amino nitrogen concentration of both groups of birds fell during the experiment but the fall was much more pronounced in the intact chickens.

The response to glucagon. The effect of a,n intracardiac injection of glucagon (10 $\mu \mathrm{g} / \mathrm{kg}$ body weight) 
was studied on three groups of chickens: intact fullyfed chickens, intact chickens, starved for $48 \mathrm{~h}$, and partially pancreatectomized chickens (Fig. 3). No sig. nificant change in the plasma insulin concentration was noted in any of the three groups of chickens following the injection of glucagon. The plasma glucose concentration of both the intact groups of chickens increased but the effect was much more pronounced in the fed chickens. The partially pancreatectomized chickens showed a small but non-significant increase in the plasma glucose concentration. The plasma FFA concentration increased significantly in all three groups of chickens. The increase was most pronounced in the intact fed and partially pancreatectomized chickens and the latter produced the greatest percentage increase in FFA concentration.

\section{Discussion}

The results presented here show clearly, for the first time, that following partial pancreatectomy in the chicken there is a marked and persistent fall in plasma insulin concentration and that this is quite independent of the nutritional status of the bird (Fig. 1).

No hyperglycaemia was observed following surgery, although the level of plasma glucose on the first day was significantly higher than in intact birds starved for $24 \mathrm{~h}$. Thus any trend towards hyperglycaemia was, perhaps, counter-balanced by the slight hypoglycaemic response to aphagia. Earlier reports on the changes in plasma glucose concentration following pancreatectomy have been conflicting. Mikami and Ono (1962) found that partial pancreatectomy led to an acute, lethal hypoglycaemia while Koike et al. (1964) and Lepkovsky et al. (1967) found that total pancreatectomy led to little or no change in plasma glucose levels.

Mikami and Ono (1962) removed only the third and splenic pancreatic lobes, which are rich in alpha islets and deficient in beta islets. It is reasonable to assume that the resultant hypoglycaemia reflected a glucagon deficiency. It is difficult, however, to reconcile this argument with the observations of Koike et al. (1964) and Lepkovsky et al. (1967) on totally, or with our own observations on partially, pancreatectomized chickens. Mialhe (1969) has suggested that the pancreatectomy was incomplete. In the experiments reported here parts of the dorsal, ventral and third lobe were removed but the splenic lobe was left intact. Considered in the light of Mikami and Ono's (1962) findings our birds might be expected to be deficient in insulin but to have almost normal levels of circulating glucagon. However, the failure of the plasma FFA concentration of the partially pancreatectomized chicks to increase during starvation (Fig. 1) may have been indicative of a glucagon deficiency. At the same time a reduction in the pancreatic avian polypeptide (Kimmel et al., 1971 ) is expected, though any physiological role of this substance remains to be elucidated.

The outcome of partial pancreatectomy in the duck depends on the nature of the remaining tissue (Mialhe, $1955 a$, 1958), while total pancreatectomy leads to profound hypoglycaemia and death (Miallhe, $1955 b$ ). Similar results have been obtained with geese by Sitbon (1967) and Mialhe (1969) although Mirsky and Gitelson (1958) found, in contrast, hyperglycaemia and glycosuria following pancreatectomy. Little work has been done with carnivorous birds. The reports of Minkowski (1893), Weintraud (1894) and Nelson et al. (1942) indicated that they became hyperglycaemic after pancreatectomy and that insulin, while lowering their blood sugar, was unable to keep them alive.

Glucose per as or intracardially produces an increase in the plasma insulin concentration of chickens (Langslow et al., 1970). Circulating glucose was removed only very slowly from the blood of the partially pancreatectomized chickens and their plasma insulin response was minimal, strongly suggesting that insulin is essential for the disposal of a glucose load. Insulin action may be suppressed in vivo in chickens by injecting anti-insulin serum and this results in pronounced hyperglycaemia (Bondareva, 1970). Taken together these pieces of evidence show that insulin is essential for the regulation of glucose utilization in chickens.

The response of the plasma FFA concentration to a glucose load was also affected in partially pancreatectomized chickens. Unlike intact birds, they did not maintain the lowered plasma FFA concentration following glucose. Thus there appeared to be a compensatory mechanism in operation which signalled the failure of glucose utilization.

There was little difference between the response of intact starved and partially pancreatectomized chickens to glucagon except that the change in plasma FFA in the starved chickens was reduced by comparison with the operated birds. This may reflect an abnormal response to starvation in the surgically operated chickens or that their fat deposits responded more readily to the action of exogenous glucagon since they were possibly deprived of endogenous pancreatic glucagon.

While insulin clearly plays a role in glucose utilization in vivo, its site of action in chickens remains unresolved. In both chicken adipose and muscle tissue, only at high concentrations does insulin stimulate the uptake and oxidation of glucose and the incorporation of glucose into glycogen, while hormone-stimulated lipolysis is unaffected (Goodridge, 1968 $a, b$; Langslow, 1970; Langslow, 1971; Langslow and Hales, 1971). Glucose uptake into heart muscle also appears insensitive to insulin stimulation, although amino acid uptake is much more sensitive (Guidotti et al., 1968). Little is known of the effect of the endocrine pancreas on liver metabolism, but it is a reasonable speculation that insulin might play a role in the regulation of glucose metabolism in this tissue.

The sensitivity of chickens to the hyperglycaemic and lipolytic actions of glucagon, both in vivo and in 
vitro (Langslow and Hales, 1969; Langslow et al., 1970; Freeman and Manning, 1971), has suggested that glucagon plays a key role in glucose and lipid homeostasis. Despite the insensitivity of chicken tissues to insulin in vitro, the extreme glucose intolerance shown by the partially pancreatectomized chicken suggests very strongly that insulin plays an essential role in the utilization of glucose.

Acknowledgements. D.R.L. was in receipt of a British Egg Marketing Board postdoctoral fellowship. We wish to thank Mr. R.J. Lewis and Mr. A.C.C. Manning for their skilled technical assistance.

\section{References}

Bondareva, V.M.: Acute insulin deficiency in chicks induced by the injection of anti-insulin serum. Dokl. Akad. Nauk SSSR, Otd. Biokh. 19, 247-249 (1970).

Freeman, B.M., Manning, A.C.C.: Glycogenolysis and lipolysis in Gallus domesticus during the perinatal period. Comp. gen. Pharm. 2, 198-204 (1971).

Goodridge, A. G.: Metabolism of glucose-U- ${ }^{14} \mathrm{C}$ in vitro on adipose tissue from embryonic and growing chickens. Amer. J. Physiol. 214, 897-901 (1968a).

- Lipolysis in vitro in adipose tissue from embryonic and growing chicks. Amer. J. Physiol. 214, 902-907 $(1968 b)$.

Guidotti, G. G., Borghetti, A. F., Gaja, G., Loreti, L., Ragnotti, G., Foa, P.P.: Amino acid uptake in the developing chick embryo heart. Biochem. J. 107, 565$574(1968)$.

Hales, C.N., Randle, P.J.: Immunoassay of insulin with insulin-antibody precipitate. Biochem. J. 88, 137-146 (1963).

Hazelwood, R.L., Kimmel, J.R., Pollock, H.G.: Biological characterization of chicken insulin activity in rats and domestic fowl. Endocrinology 83, 1331-1336 (1968).

Heald, P.J., McLachlan, P.M., Rookledge, K.A.: The effects of insulin, glucagon and adrenocorticotrophic hormone on the plasma glucose and free fatty acids of the domestic fowl. J. Endocr. 33, 83-95 (1965).

Huggett, A.St.G., Nixon, D.A.: Enzymic determination of blood glucose. Biochem. J. 66, 12P (1957).

Kimmel, J.R., Pollock, H.G., Hazelwood, R.L.: A new pancreatic polypeptide hormone. Fed. Proc. 30, 1318 (1971).

Koiko, T.I., Nalbandov, A.V., Dimick, M.K., Matsumura, Y., Lepkovsky, S.: Action of insulin upon blood glucose levels of fasted hypophysectomized. depancreatized and normal chickens. Endocrinology 74, 944-948 (1964).

Langslow, D.R.: Studies on the regulation of carbohydrate and lipid metabolism in the domestic fowl. Ph.D. Thesis, University of Cambridge (1970).

- The anti-lipolytic action of prostaglandin $\mathrm{E}_{1}$ on isolated chicken fat cells. Biochim. biophys. Acta (Amst.) 239, 33-37 (1971)

- Butler, E.J., Hales, C.N., Pearson, A.W.: The response of plasma insulin, glucose and non-esterified fatty acids to various hormones, nutrients and drugs in the domestic fowl. J. Endocr. 46, 243-260 (1970).

- Hales, C.N.: Lipolysis in chicken adipose tissue in vitro. J. Endocr. 43, 285-294 (1969).

- Hales, C.N.: The role of the endocrine pancreas and catecholamines in the control of carbohydrate and lipid metabolism, in "Physiology and Biochemistry of the Domestic Fowl", Ed. Bell, D.J., and Freeman, B.M. Vol. 1, 521-548. London: Academic Press 1971.

- Kimmel, J.R.: The half-life of chicken and ox insulin in chickens and the effect of iodination on the half-life. Submitted for publication (1972).

Laurell, S., Tibling, G.: Colorimetric micro-determination of free fatty acids in plasma. Clin. chim. Acta 16, 57-62 (1967).

Lepkovsky, S., Dimick, M.K., Furuta, F., Snapir, N. Park, R., Narita, N., Komatsu, K. : Response of blood glucose and plasma free fatty acids to fasting and to injection of insulin and testosterone in chickens. Endocrinology 81, 1001-1006 (1967).

Lukens, F.D.W.: Alloxan diabetes. Physiol. Rev. 28, $304-330$ (1948).

Mialhe, P.: Diabète passager et diabète permanent après pancréatectomie subtotale chez le canard. C.R. Acad. Sci. (Paris) 241, 1851 (1955 $\alpha$ ).

- Hypoglycémie et diminution de la tolérance au glucose chez le canard après pancréatectomie totale. C.R. Acad. Sci. (Paris) 241, $1500(1955 b)$.

- Glucagon, insuline et régulation endocrine de la glycémie chez le canard. Acta endocr., (Kbh.) Suppl. 36 (1958).

- Some aspects of the regulation of carbohydrate metabolism in birds. Proc. 3rd Int. Conf. Endocr. Mexico $158-163$ (1969).

Mikami, S.-I., Ono, K.: Glucagon deficiency induced by extirpation of alpha islets of the fowl pancreas. Endo. crinology 71, 464-473 (1962).

Minkowski, O.: Untersuchungen über den Diabetes mellitus nach Exstirpation des Pankreas. Naunyn-Schmiedeberg's Arch. Pharmak. 31, 85-189 (1893).

Mirsky, I.A., Gitelson, S. : Comparison of the hypoglycaemic action of tolbutamide in the fowl and other species. Endocrinology 61, 148-152 (1957).

- - The diabetic response of geese to pancreatectomy. Endocrinology 63, 345-348 (1958).

Moore, S., Stein, W.H.: A modified ninhydrin reagent for the photometric determination of amino acids and related compounds. J. biol. Chem. 211, 907-913 (1954).

Nelson, N., Elgart, S., Mirsky, I.A.: Pancreatic diabetes in the owl. Endocrinology 31, 119-123 (1942).

Scott, C.C., Harris, P.N., Chen, K.K. : Efrects of alloxan in birds. Endocrinology 37, 201-207 (1945).

Sitbon, G.: La pancréatectomie totale chez l'oie. Diabetologia 3, 427-434 (1967).

Smith, L.F.: Species variation in the amino acid sequence of insulin. Amer. J. Med. 40, 662-666 (1966).

Weintraud, W.: Über den Pankreas - Diabetes der Vögel. Naunyn-Schmiedeberg's Arch. Pharmak. 34, 303-$312(1894)$.

D.R. Langslow, Ph.D.

Houghton Poultry Research Station, Houghton, Huntingdon PE 17 2DA, England 